\title{
SOURCE, TRANSPORTATION AND DEPOSITION OF DEBRIS ON ARAPAHO GLAGIER, FRONT RANGE, GOLORADO, U.S.A.
}

\author{
By Marith Jean Reheis \\ (Department of Geological Sciences and Institute of Arctic and Alpine Research, University \\ of Colorado, Boulder, Colorado 80302, U.S.A.)
}

\begin{abstract}
This study was undertaken to determine the sources of debris and methods of transportation and deposition in and on a small cirque glacier. Data were collected on the amount of debris, stone roundness, the presence of striations and polish, and till fabric. Lichenometry gave relative ages of the tills, and suggests that the Gannett Peak till is of at least three ages and probably overlies Audubon till.

Debris originating from subglacial erosion can be differentiated from that from rockfall or avalanches on stone roundness, polish and striations. A maximum of $70 \%$ of the present glacial load derives from subglacial erosion, as compared to $88 \%$ during the Gannett Peak stade. Rockfall rates are $35-50 \mathrm{~m}^{3} /$ year at present and were $290-485 \mathrm{~m}^{3} /$ year during the Gannett Peak stade. Data on present-day processes and on the volume and age of Gannett Peak moraines can be used to make comparisons on present and past rates of denudation. The denudation rate in the cirque at present is $95^{-1} 65 \mathrm{~mm} / \mathrm{I}$ ooo year; in the past it was $4920-8 \mathrm{I} 60 \mathrm{~mm} /$ I ooo year. The denudation rate and the glacial effects on debris are comparable to rates from other glacial areas and effects on debris carried by valley glaciers and continental ice sheets.
\end{abstract}

RÉsumÉ. Origine, transport et dépôt de blocs sur le Arapaho Glacier, Front Range, Colorado, U.S.A. Cette étude a été entreprise pour connaître les origines et les modes de transport et de dépôt de blocs rocheux sur un petit glacier de cirque et à l'intérieur du glacier. Les échantillons ont été ramassés parmi les blocs, pierres polies, avec stries et poli glaciaire, en provenance d'une structure morainique. L'étude des lychens donne l'âge relatif des moraines et suggère que la moraine de Gannett Peak est du plus petit des 3 âges glaciaires, et probablement recouvre la moraine Audubon.

Des blocs provenant d'érosion sous glaciaire peuvent être différentiés de ceux provenant de chutes de rochers ou d'avalanches par la forme arrondie, le poli et les stries. Un maximum de $70 \%$ du matériel glaciaire actuel provient d'érosion sous-glaciaire alors que pendant la période Gannett Peak la proportion est de $88 \%$. Le taux de chute de rochers est de 35 à $50 \mathrm{~m}^{3}$ par an à l'heure actuelle, et il était de 290 à $485 \mathrm{~m}^{3}$ par an pendant la période Gannett Peak. Les procédés relatifs aux informations actuelles, volume et âge des moraines de la période Gannett Peak, peuvent être utilisées pour faire des comparaisons entre les taux d'érosion du présent et du passé. Le taux d'érosion dans le cirque glaciaire est à l'heure actuelle de 95 à I $65 \mathrm{~mm}$ par I ooo ans. Dans le passé, il était de 4920 à 8 I $60 \mathrm{~mm}$ par I ooo ans. Le taux d'érosion et les actions glaciaires sur les blocs de moraines sont comparables aux taux d'érosion des autres surfaces glaciaires et aux actions sur les blocs charriés par les glaciers de vallée, et les calottes glaciaires continentales.

Zusammenfassung. Ursprung, Transport und Ablagerung des Schutts am Arapaho Glacier, Front Range, Colorado, U.S.A. Diese Untersuchung wurde durchgeführt, um Herkunft sowie Transport- und Ablagerungsweise von Schutt in und auf einem kleinen Kargletscher zu bestimmen. Dabei wurden Beobachtungen über die Menge des Schutts, die Abrundung der Steine, das Vorhandensein von Schrammen und Politur und über die Struktur der Ablagerungen angestellt. Flechtenmessungen lieferten Angaben über das Alter der Geschiebe; sie lassen den Schluss zu, dass die Gannett Peak-Geschiebe aus mindestens 3 Perioden stammen und wahrscheinlich über Audubon-Geschieben liegen.

Auf Grund der Abrundung, Politur und Schrammung der Steine kann der von subglazialer Erosion herrührende Schutt von dem durch Steinschlag oder Lawinen herbeigebrachten unterschieden werden. Maximal $70 \%$ der jetzigen Schuttlast des Gletschers geht auf subglaziale Erosion zurück, verglichen mit $88 \%$ während der Gannett Peak-Periode. Die Menge des Steinschlages beträgt gegenwärtig etwa $35-50 \mathrm{~m}^{3}$ Jahr gegenüber $290-485 \mathrm{~m}^{3} / \mathrm{Jahr}$ während der Gannett Peak-Periode. Mit Hilfe von Daten über gegenwärtige Vorgänge und über Volumen und Alter der Gannett Peak-Moränen können Vergleiche zwischen heutigen und früheren Denudationsgeschwindigkeiten angestellt werden. Die Denudationsgeschwindigkeit im Kar beträgt gegenwärtig $95^{-165} \mathrm{~mm} / \mathrm{I}$ ooo Jahre, gegenüber $4920-8 \mathrm{r} 60 \mathrm{~mm} / \mathrm{I}$ ooo Jahre in der Vergangenheit. Die Denudationsgeschwindigkeit und die Wirkungen des Eises auf den Schutt lassen sich mit den Werten anderer Gletscherregionen vergleichen, etwa bei Talgletschern und kontinentalen Eisdecken.

\section{INTRODUCTION}

Detailed studies of existing glaciers have been performed in many areas of the world for well over a century. The majority of these studies have concentrated on ice movement and glacial mass and energy balance, but there has been a general absence of research on modern glacier processes relevant to glacial geology. As a result, theories of transportation mechanisms and glacial deposition rest largely on information from studies of till rather than on information derived from active glaciers. In addition, studies on existing glaciers have 
been mainly concerned with ice bodies of at least valley-glacier size up to those of ice-cap dimensions. There is at present an obvious gap between glacial geology and glaciology.

This study attempts partially to fill that gap by considering the sources of debris and the methods of transportation and deposition of debris of a small cirque glacier at present and during the recent past, and to evaluate methods and rates of bedrock erosion. An attempt was also made to determine if there had been any changes in source of debris, and in the transport and deposition of debris, by an analysis and comparison of both the material currently in transport by the glacier and the material previously deposited in the neoglacial moraine.

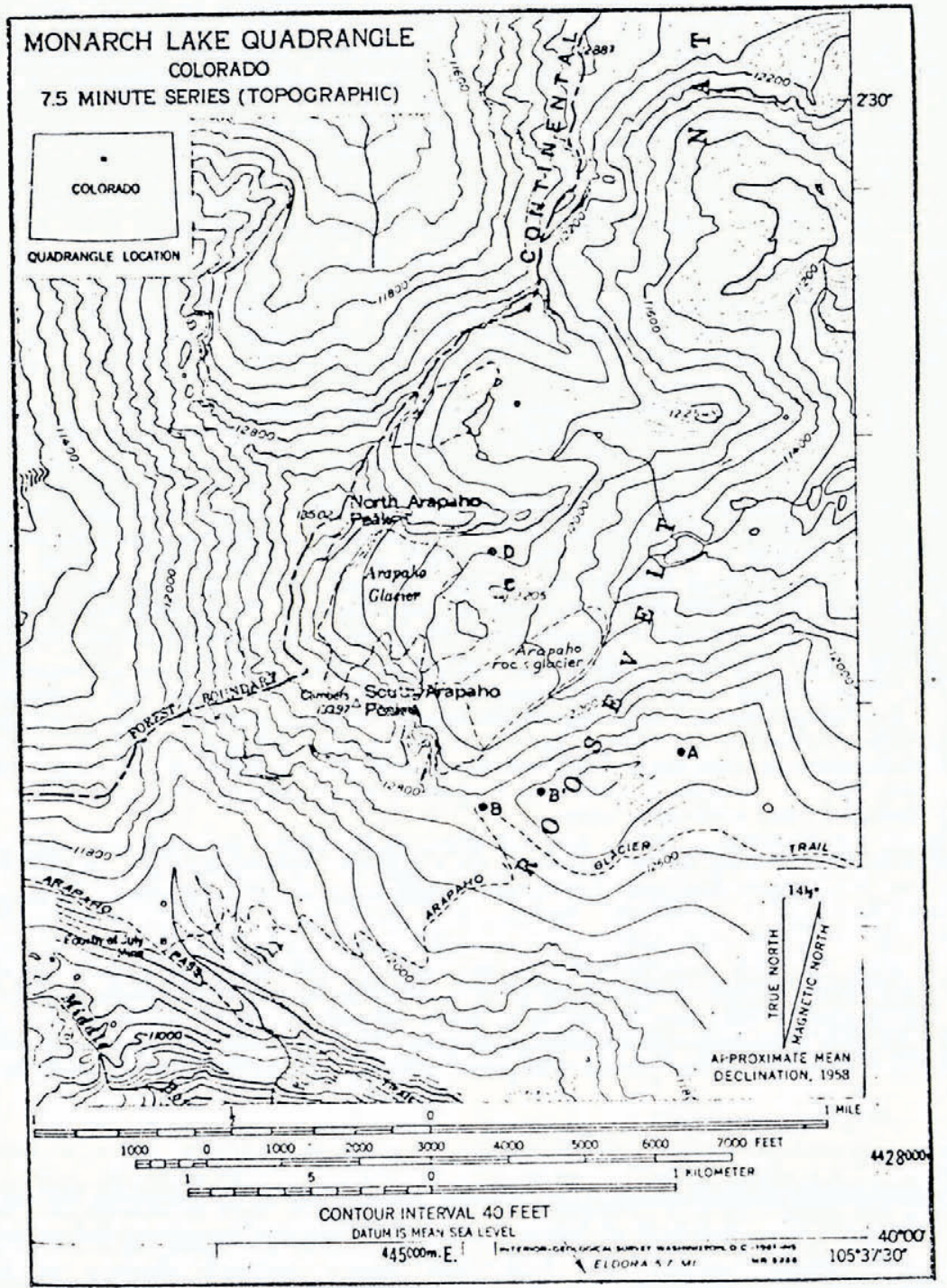

Fig. I. Arapaho Glacier area. 


\section{Arapaho Glacier}

Arapaho Glacier is a small cirque glacier, but the largest in Colorado. It lies in the Colorado Front Range and ranges from 4054 to $3680 \mathrm{~m}$ in elevation (Figs. I and 2). Crevasses in mid-glacier penetrate $17 \mathrm{~m}$ of ice.

The climate in the cirque may be approximated with data from the Niwot Ridge weather station, $5 \mathrm{~km}$ to the north-east. There, the mean annual air temperature is $-3.8^{\circ} \mathrm{C}$, the ablation season average temperature (June, July, August) is $6.8^{\circ} \mathrm{C}$, the average annual precipitation is $102 \mathrm{~cm}$, and the average wind velocity is $10.3 \mathrm{~m} / \mathrm{s}$ (Barry, 1972). Snow accumulation is much higher in the cirque due to wind-drift accretion in the lee of the continental divide.

Rotational slip probably accounts for most of the glacier motion, as indicated by the changing dip angles of the accumulation layers in the ice and firn. Some internal deformation is indicated by the decrease in ice velocity from $5.2 \mathrm{~m} /$ year at the firn line to $1.7 \mathrm{~m} /$ year at the terminus of the southern lobe of the glacier (Waldrop, 1964 ; 1960-6i data). Alford (unpublished) measured a mean specific winter balance of $+330 \mathrm{~cm} \mathrm{H}_{2} \mathrm{O}$, and a mean specific summer balance of $-305 \mathrm{~cm} \mathrm{H}_{2} \mathrm{O}$, for the $1969-70$ balance year. The high value of mass exchange, or the sum of the absolute values of the mean specific winter and summer balances,

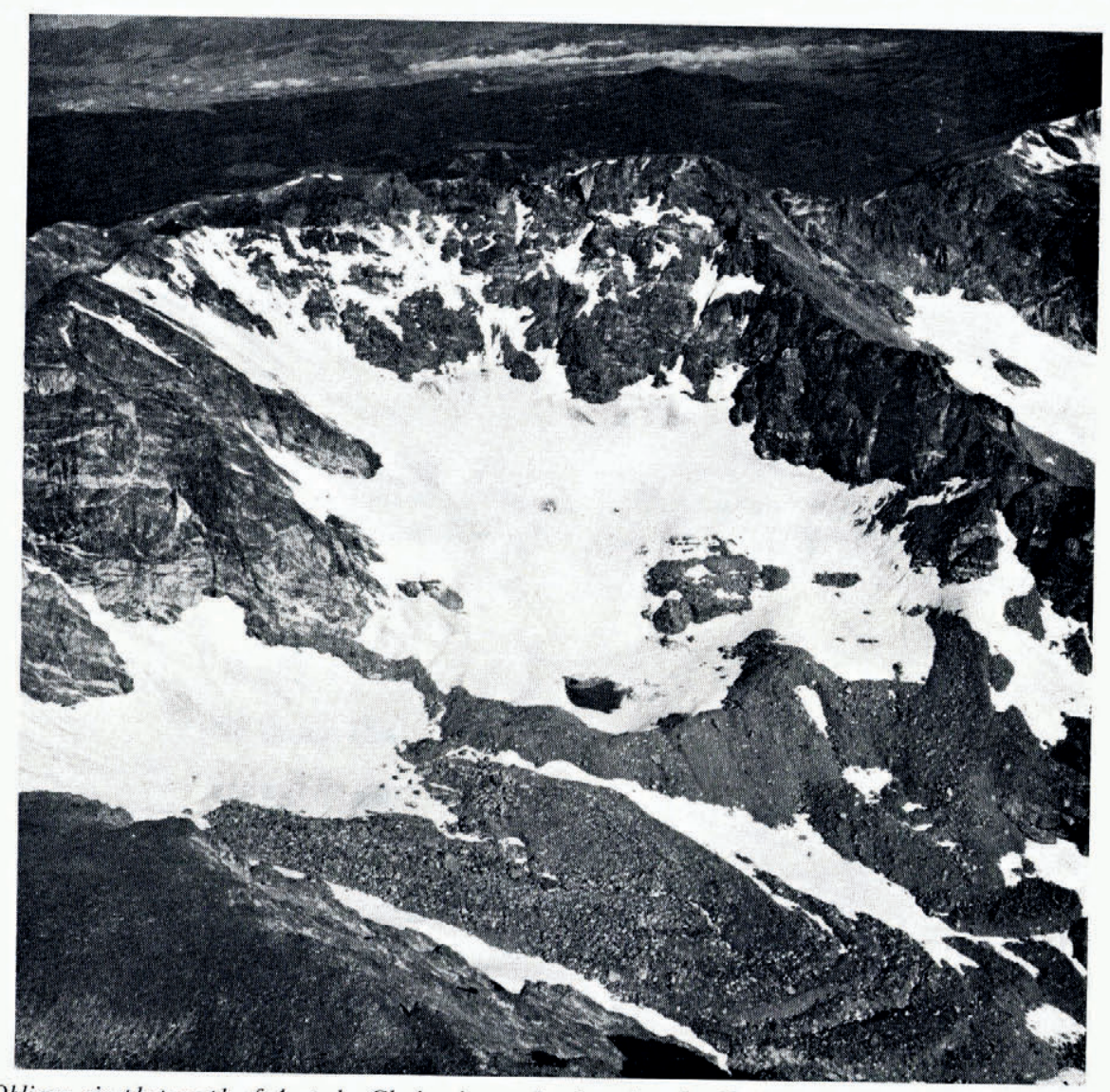

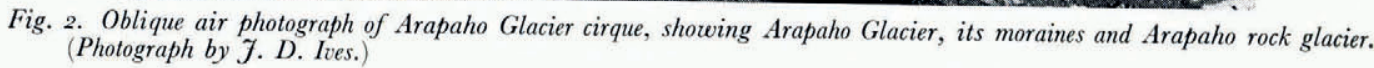


would appear to indicate that Arapaho Glacier should have a high potential for glacial erosion.

The glacier has undergone extensive retreat in the past Ioo years, having lost over $30 \%$ of its area and having thinned considerably (Waldrop, 1964). Since about 1960 , however, it has remained fairly stable, as shown by evidence which indicates that the mass balance of the glacier has been zero to slightly positive (Alford, unpublished; personal communication from J. B. Johnson, i 973).

\section{Methods}

The parameters sampled characterized the debris; they included lithology, roundness, striations, polish, and surface and sub-surface till fabrics. Debris sampling was done at 26 sites on the moraines and the glacier for every stone touched by a $20 \mathrm{~m}$ long tape laid out on the surface; in addition, small pebbles $2-10 \mathrm{~mm}$ in diameter were taken from each site and examined under a binocular microscope.

The relative age of the debris is based on diameters of Rhizocarpon geographicum (?), a slowgrowing species with a known growth rate (Benedict, 1967 ), and Lecanora thompsonii, a fastgrowing species. Lichens were sampled at 63 sites of $25 \mathrm{~m}^{2}$ on the terminal moraine. Up to five large individuals of each species were recorded; only the maximum diameters of the two species at each location are presented here. The assumptions upon which lichenometry is based and its biological prerequisites and limitations have been discussed by many workers (cf. Beschel, I96I ; Benedict, I967; Webber and Andrews, 1973).

Suspended sediment in the moraine lake outlet was measured using a Norwegian sediment sampler.

Sand-sized quartz grains were separated from samples collected from several sites on the moraine and on the glacier ice. In order to try to differentiate grains that had been transported in different ways, the surfaces of the quartz grains were examined using a scanning electron microscope (Cambridge Stereoscan Model S-4).

The raw data and detailed descriptions of sampling and laboratory techniques may be found in my thesis (Reheis, unpublished).

\section{Model for derivation and transportation of debris}

The debris Arapaho Glacier carries derives from three sources: rockfall off the cirque walls, rock debris contained in avalanches, and glacial quarrying and abrasion of the bedrock. It is next to impossible to differentiate debris derived by rockfall from that contributed by

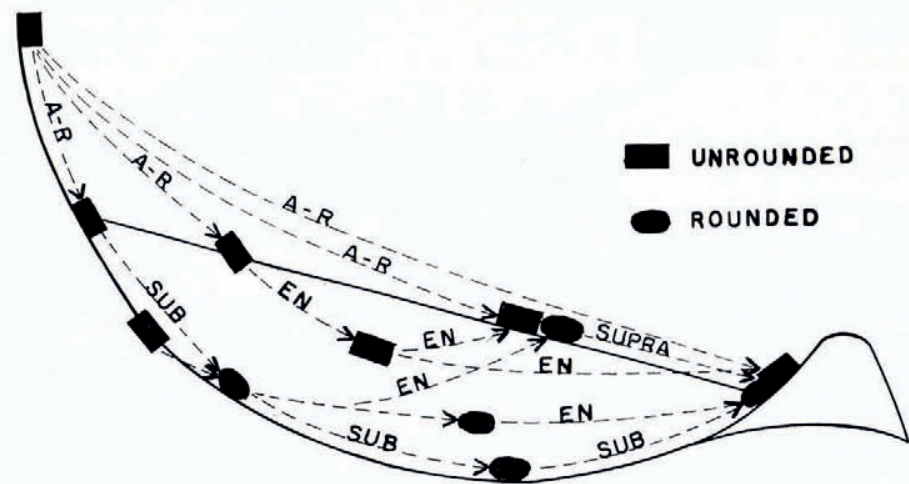

Fig. 3. Schematic diagram showing sources of debris and possible paths of travel through a small cirque glacier. Solid blocks represent unrounded material; solid ovals represent rounded material. Avalanche and rockfall debris is indicated by $A-R$; SUPRA means supraglacial transport; EN means englacial transport; SUB means subglacial transport. 
avalanches, particularly once the debris has been covered by the next year's snow accumulation. Hence, avalanche and rockfall material will be considered together as rockfall debris.

Transport of debris occurs in several ways on Arapaho Glacier. These include subglacial, englacial and supraglacial transport, movement along shear planes (probably negligible), and rockfalls or avalanches which carry material across the glacier directly to the moraine. Interplay among the various sources of debris and the modes of transportation is complex (Fig. 3).

\section{Relative AGe of MORAine AREAS}

The moraine fronting Arapaho Glacier (Fig. 2) has generally been considered as Gannett Peak, or no more than about 300 years old (Benedict, I968). Benedict has mapped the northeastern part of the moraine as an Audubon ( $185^{\circ}-95^{\circ}$ years B.P.) rock glacier, and has mapped the extreme northern edge as an Audubon lateral moraine. Lichenometry was used to test these age assignments and to see if Gannett Peak debris represents one or more different age groups and hence depositional episodes.

Six age groups are recognized on a basis of similarity of lichen diameters (Fig. 4). Application of the non-parametric Kolmogorov-Smirnov test (Campbell, i 967 ) for significant differences in the populations from which the lichen diameters were drawn indicated that the groupings are valid for $L$. thompsonii, but were generally invalid for $R$. geographicum (?). This result merely indicates that slow-growing $R$. geographicum (?) lichens are not useful for making fine age distinctions on very young deposits.

Tills of different ages form the moraine south of survey point A (Fig. 4). The lichen data support at least three (groups I, 2 and 3 and/or 4) and not more than five intervals of deposition during the Gannett Peak stade. Three is probably the more accurate figure in consideration of the effects of snowkill and the instability of the substrate on the steep morainal slopes.

The lichen diameters in group 6 are decidedly larger than those in any of the other groups. $R$. geographicum (?) diameters range up to $30 \mathrm{~mm}$ and the $L$. thompsonii diameters up to I $13 \mathrm{~mm}$. The north-eastern area of the moraine falls within group 6 and is classed as Audubon by Benedict (I968). Two additional areas of group 6 lie on the southern boundary of the till on the distal slope. The lichens in those two areas were measured on large angular boulders with a relatively high percentage lichen cover as compared to the surrounding debris. If these lichen-covered boulders are not of rockfall origin off the cirque walls, they could be Audubon till partially masked by Gannett Peak till. If so, the accumulation of till in the moraine fronting the glacier could have occurred over I 200 years rather than only 300 years; this may help to explain how a small glacier like Arapaho Glacier could produce the tremendous volume of debris in its moraine.

\section{Characteristics of the till}

A major problem was to find some means of determining the various sources and transportation mechanisms which affected rock fragments in the till. During glacial transport, rock fragments may be rounded, striated, polished or not affected at all; the effect produced is dependent on the mode of transportation and the lithology of the stones. In a cirque glacier which rotates as a rigid body, stones must be moved relative to bedrock to become polished, striated or rounded. In addition, till fabric may provide clues on the transporting mechanism.

In recent years, many workers (Krinsley and Donahue, I968; Margolis and Kennett, I97I; Brown, I973) have attempted to use electron microscopy to determine the depositional histories of quartz sand grains based on surface textures characteristic of various transportational processes. This technique was attempted here on quartz grains collected from moraines and glacier ice, including subglacial, englacial, supraglacial and rockfall sites. However, 


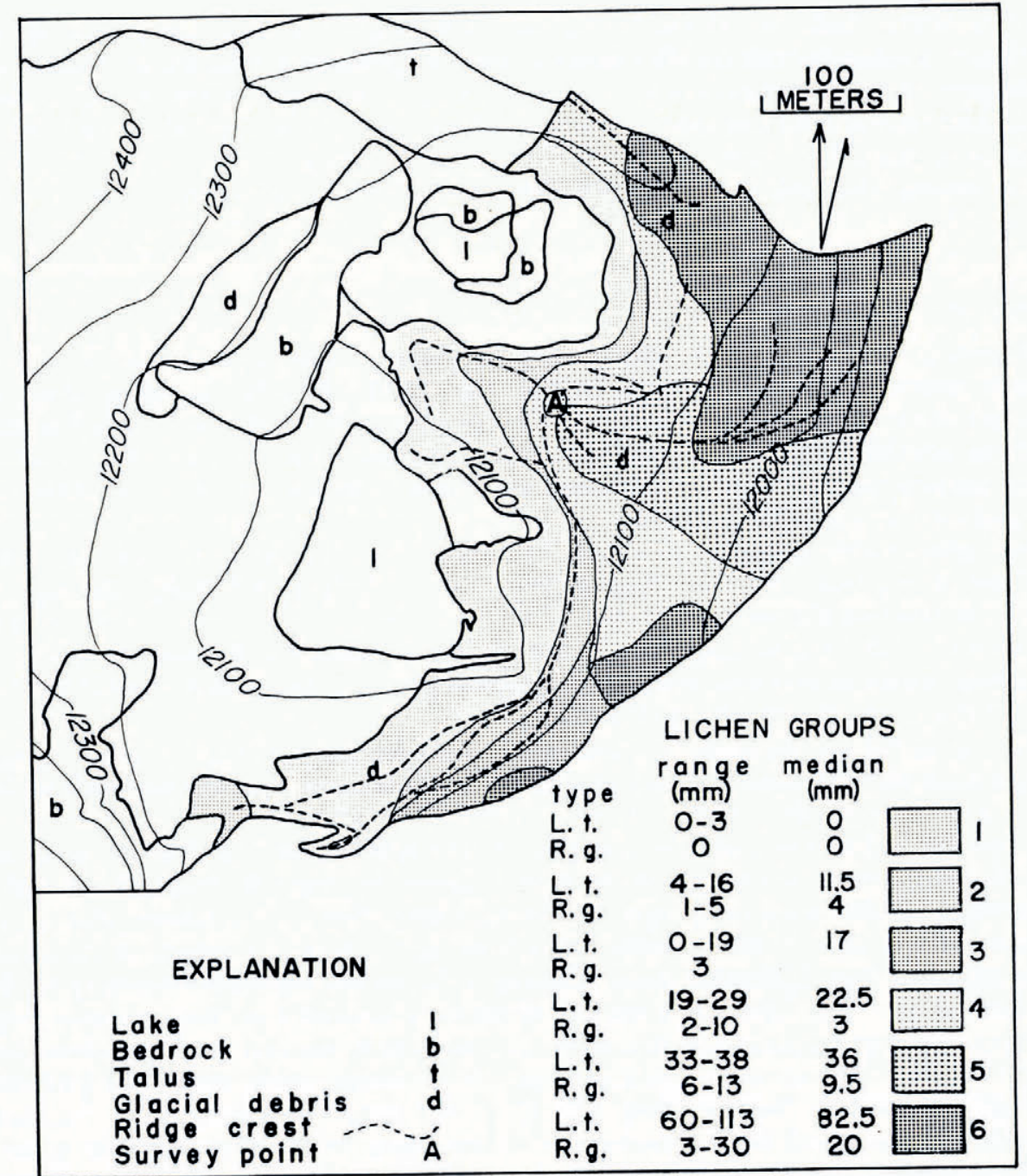

Fig. 4. Relative age groups of debris on the terminal moraine, based on lichen diameters. L.t. stands for L. thompsonii, R.g. for R. geographicum (?).

features diagnostic of glacial textures and of chemically weathered textures were found on grains from all sites. It was concluded that electron microscopy on grains in the till could give no conclusive evidence concerning the amounts of material contributed to a glacier by various sources.

Preliminary observations on debris in different parts of the moraine and glacier indicated varying degrees of rounding and occurrences of striations and polish. These three characters are closely associated; it is worthwhile to note that polish and striations were never found on stones with a roundness of only o.I. To examine these characteristics in greater detail, two maps were constructed: one showing the average roundness of stones and the percentage of stones rounded $>$ o. I at each sampling site, and one showing the percentages of striated and polished stones at each site (Fig. 5). The sampling sites were divided into four groups on the basis of these characteristics. These four groups were tested for differences in populations 
using the Kolmogorov-Smirnov test (Campbell, r967) and were found to be significantly different for all characteristics at a $5 \%$ confidence level.

Group A shows the least amounts of polish, striations and degree of rounding, and includes sites on the Audubon rock glacier, on the northern limb of the moraine, and on the ablation moraine and the glacier. The site on the northern limb receives talus from the cirque wall

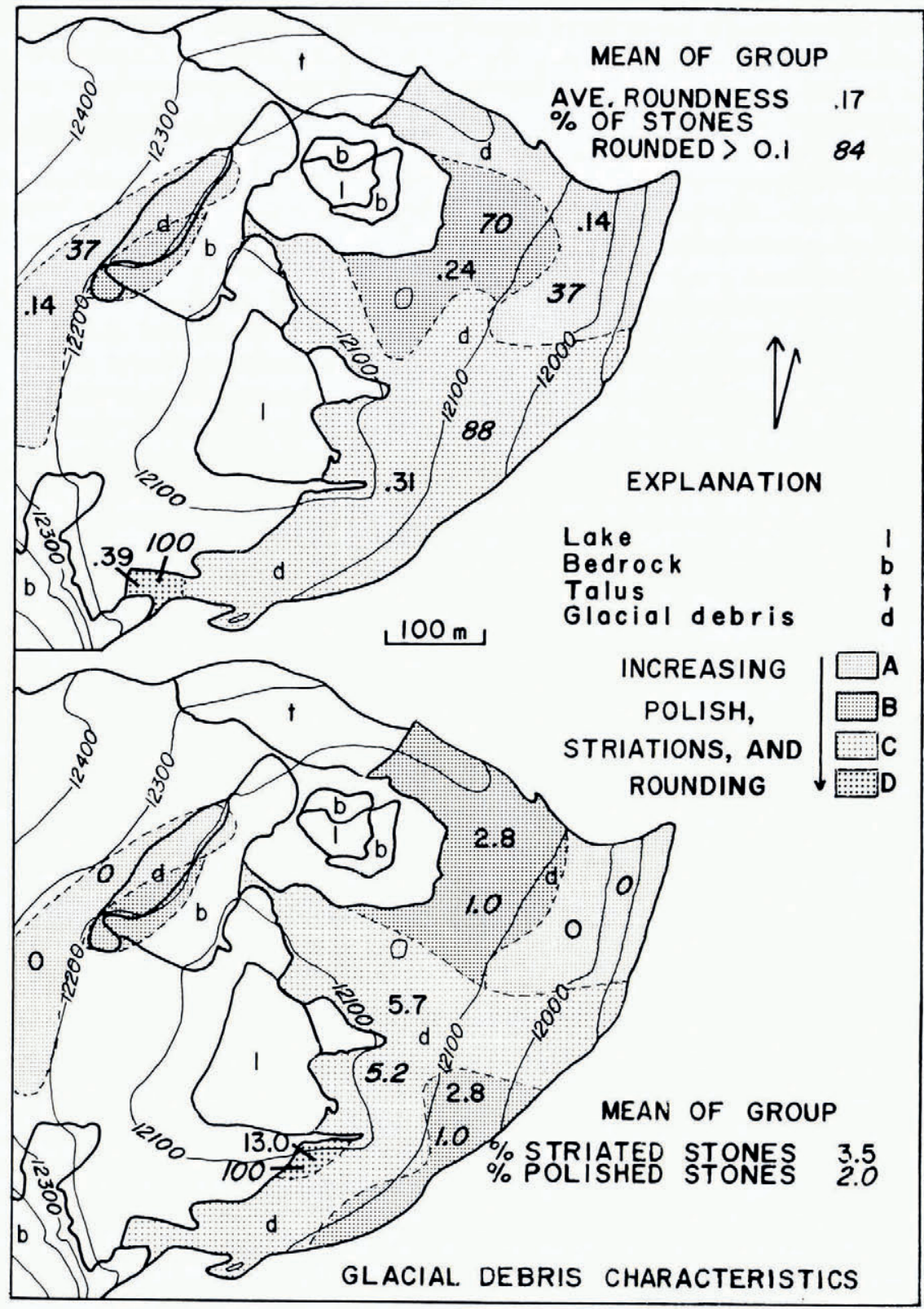

Fig. 5. Glacial characteristics of the debris are compared in two maps, one with two aspects of roundness and one with percentages of striated and polished stones. These characters were used to divide the moraine into four areas representing debris which exhibits varying amounts of the effects of subglacial transportation. 
above. That area and the rock glacier down-valley were deposited by the northern lobe of the glacier, suggesting that that lobe had less effect on the material it carried than did the southern lobe of the glacier. Sites on the ablation moraine and the glacier probably consist largely of englacial material (Fig. 3).

One site on the ablation moraine and, in general, the northern half of the bilobate moraine comprise group B. Debris in the ablation moraine lies partly on the bedrock knob which might induce rounding, striations and polish. Data from the other sites support the notion above that the northern lobe of the glacier was generally less active than the southern one.

The highest degree of rounding and the most polish and striations are exhibited by sites in the southern half of the moraine (groups $\mathrm{C}$ and $\mathrm{D}$ ). This suggests that the southern ice lobe contributed more subglacial material to the terminal moraine.

The amount of roundness, and occurrences of striations and polish, might significantly be controlled by lithology (Holmes, I 960). In order to test this hypothesis, a study was made of the relative proportions of rounding, striations and polish among pegmatites, schists, coarsegrained gneisses, fine-grained gneisses and hornblendites in the moraines. Contingency tables were constructed for comparison of the occurrence of polish and striations, and the amount of rounding (range 0. I-0.6 on the Powers scale), with these lithologic types. At a $5 \%$ level of confidence, the results showed that the fine-grained hornblende-gneisses and the hornblendites proportionally exhibit significantly greater amounts of striations, polish and rounding than do the coarser-grained gneisses, pegmatites and schists. However, the finegrained rocks should have little effect on the data because they constitute only $6 \%$ of the sampled debris.

The characters of till, discussed above, are also a function of the distance of glacial transport. Goldthwait (I97I) stated that rounding of stones will increase from 0.1 to 0.5 in the first mile of transport; till of Arapaho Glacier has been carried slightly over 0.5 mile $(0.8 \mathrm{~km})$, and the maximum roundness of stones was found to be o.6. Drake (197I) reported that basally deposited continental till, similar in lithology to Arapaho Glacier till, has roundness (o.48) and per cent of stones striated (2.9) that are comparable to the till in this study. A maximum average roundness of 0.39 and $13 \%$ of stones striated was found on the Arapaho Glacier moraine. An average of $0.1 \%$ striations was reported for a continental ablation till (Drake, 197 I) and this is comparable to striation frequency on englacial debris from the glacier and the ablation moraine (Fig. 5).

Rounding, striations and polish are, in summary, three associated characters which can be used to differentiate subglacially derived and transported stones from those derived from other sources and carried in other ways. Striations and polish, however, occur on a very small proportion of the debris (Fig. 5) and this is probably a function of the predominantly coarse-grained lithologies present.

\section{Present Sources AND transportation of Debris}

Estimates of the contributions of the various sources and transportation mechanisms can be made based on the percentage of rounded stones. A stone is considered rounded if its roundness is greater than o.I. It is assumed that debris which shows even a slight degree of rounding has been subglacially transported at some time during its history, while completely angular debris was derived from rockfall and has undergone only englacial, supraglacial, rockfall or avalanche transport (Fig. 3). The complex interplay of rockfall and avalanche accretion with englacial and supraglacial transport precludes the possibility of identifying material moved by an individual mechanism, so these types of transportation will be considered together. Hence, discussions that follow will attempt to differentiate between material that has been carried subglacially at some time and material that has undergone only englacial transport. 
Estimates of the present contributions of various sources of debris, and on the modes of transport, were derived from five sampling sites located on the ablation moraine and on the ice immediately to the south in the central part of the glacier (Fig. 5). Two complicating factors are present. (I) The bedrock knob below the ablation moraine may be forcing the ice behind it to behave as if it were in a small sub-cirque, while the presence of this bedrock high would induce more rounding. (2) The fact that the samples used for the estimates are from the central part of the glacier means that they cannot be wholly representative of the total glacial product.

Taking Waldrop's ( 1964 ) figure of $0.9 \mathrm{~m}$ for the average thickness of the ablation moraine, and assuming that this deposit has been produced in a time span of $30-50$ years during the rapid retreat of the glacier, I obtain a volume of $470 \mathrm{~m}^{3}$ and an average rate of production of $9.4^{-1} 5.7 \mathrm{~m}^{3} /$ year (these and all subsequent volumes and rates have been adjusted to allow for $40 \%$ pore space in the moraine). Of that amount, rounded debris (subglacially eroded and transported) comprises $35 \%$ or $3.3-5.5 \mathrm{~m}^{3} /$ year, and unrounded debris (rockfall or avalanche material carried englacially or supraglacially) comprises $65 \%$ or $6 . \mathrm{I}-10.2 \mathrm{~m}^{3} /$ year. The area of ice which contributes debris to the ablation moraine is approximately $20 \%$ of the entire glacier. Assuming that the debris production of this portion of ice is representative of the entire glacier, I obtain rates of $15-30 \mathrm{~m}^{3} /$ year $(30-60 \mathrm{~mm} / \mathrm{I}$ ooo year) for rounded material

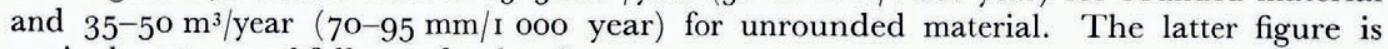
equivalent to a rockfall rate for the cirque.

The ablation moraine lies at a position a little more than half the distance from the headwall to the main part of the terminal moraine. Stones in the ablation moraine have therefore been carried only about half as far as stones in the terminal moraine. A reasonable assumption might be that transporting material from the headwall to the moraine could result in twice the number of rounded stones that occur in the ablation moraine. This assumption yields a present approximate production of $70 \%$ subglacially transported debris and $30 \%$ rockfall debris carried englacially or supraglacially.

To obtain the present rate of debris transport by Arapaho Glacier, an estimate of the volume of debris in the ablation moraine was combined with suspended sediment measurements made in mid-July and late August of 1972 at the moraine lake outlet on the east shore. The bedload of the stream may safely be ignored because all drainage occurs through the moraine. Error in the amount of suspended sediment load may be quite high, owing to the short time span covered by measurements, and the probable existence of other subterranean drainages. In addition, discharge records for the summer of 1972 were irregular owing to repeated malfunctions of the stream-level recorder. Accordingly, the following figures for rates and volumes from suspended sediment data must be taken as minimum estimates.

Assuming that discharge through the moraine occurs only in the summer for an average of $100 \mathrm{~d} /$ year, the yearly load of suspended sediment carried by the outlet stream ranges from I.o to $4.7 \mathrm{~m}^{3}$. Because the area of the cirque is $514740 \mathrm{~m}^{2}$, a denudation rate of $2-9 \mathrm{~mm} /$ I ooo year is obtained. A rate of $9.4^{-1} 5.7 \mathrm{~m}^{3} /$ year for the production of the debris in the ablation moraine was given previously. If the area of ice contributing material to the ablation moraine constitutes $20 \%$ of the total glacier area and is representative of the whole glacier, present deposition occurs at $48-82 \mathrm{~m}^{3} /$ year or a denudation rate of $93^{-1} 55 \mathrm{~mm} / \mathrm{I}$ ooo year. Combining the figures obtained from the ablation moraine with those on suspended sediment, a total denudation rate of between 95 and $165 \mathrm{~mm} / \mathrm{s}$ ooo year is obtained.

\section{PAST SOURCES, TRANSPORTATION AND DEPOSITION OF DEBRIS}

Data on stone roundness for the Gannett Peak moraine (Figs. 4 and 5) can be used to calculate past relative contributions of the various sources and of the various transportation mechanisms. If an estimate of ${ }^{5} 5^{-25} \mathrm{~m}$ is used for the average thickness of the moraine, and 
its area is $80945 \mathrm{~m}^{2}$, a total of $728000-1214000 \mathrm{~m}^{3}$ is obtained for the volume of Gannett Peak debris in the terminal moraine. Assuming the Gannett Peak stade lasted approximately 300 years, the rate of production of debris was $2430-4050 \mathrm{~m}^{3} /$ year. Data from 16 sampling sites on the moraine indicate that $88 \%$ of the debris is rounded, and thus derived and/or carried subglacially; the remainder is unrounded and thus derived by rockfall, and carried englacially or supraglacially. These data yield a production rate for rounded debris of $2 \mathrm{I}_{40}-356 \mathrm{o} \mathrm{m}^{3} /$ year and for unrounded debris of $290-485 \mathrm{~m}^{3} /$ year.

Calculation of the total volume of Gannett Peak material deposited by Arapaho Glacier should give an estimate of the rate of debris transport and deposition over the last 300 years. The volume of the Gannett Peak part of the end moraine was given as $728000-1214000 \mathrm{~m}^{3}$. If the average thickness of the ground moraine beneath the lake is $3-5 \mathrm{~m}$, its volume is $32000-53000 \mathrm{~m}^{3}$. The volume of the ablation moraine is approximately $785 \mathrm{~m}^{3}$. Over the whole of Gannett Peak time, transport of debris occurred at $2500-4200 \mathrm{~m}^{3} /$ year for a denudation rate of 4 920-8 $160 \mathrm{~mm} / \mathrm{I}$ ooo year.

Deposition of glacial debris is the process which forms the link between debris sources and transportation methods on the one hand, and till deposits, which frequently constitute the only remaining evidence of former glaciation, on the other. Data on deposition are derived from a study of till fabric. It is recognized that the stones in an undisturbed till usually possess a fabric best shown as preferred orientations and dips of the stones. Boulton (1970, 197I) pointed out that either transverse or parallel preferred stone orientations may be exhibited by ablation, melt-out or lodgement till, depending on a number of factors. Without collecting exhaustive data, it seems impossible to differentiate between the three types of till in Arapaho Glacier cirque except in a very general way.

Data on surface and sub-surface till fabrics allow some division of sampling sites. The tillfabric strength at each of 26 sites was calculated by applying the $\chi^{2}$ test, assuming that if the stones were not orientated, the numbers of stones should be equally distributed in all directions (Reheis, unpublished). Surface sites with relatively strong till fabrics are, in general, those in the southern half of the moraine, plus one site on the ablation moraine. Areas on the moraine with relatively weak till fabrics are generally those in which subsequent movement of material by surficial processes is expected, such as the steep down-valley side of the moraine, and in the northern talus-fed area.

Till fabrics combined with information on plunge, taken from below the moraine surface, provide the best information about the deposition of debris (site locations are shown on Figure 6 ). At site 3 the preferred orientation is down-slope, which could indicate a strong component of mass movement. However, all the stones plunged down at an angle $10^{\circ}$ less than the dip of the moraine slope; therefore, this orientation may represent the original one parallel to the direction of glacial movement and later modified by mass movement. If so, site 3 consists either of melt-out till or lodgement till, probably the latter. At site 5 , the stones have a plunge equal to the slope angle, suggesting a combination of melt-out and ablation till. Stones at site 7 nearly all plunge down into the moraine slope, representing either melt-out or lodgement till. There is a predominance of stones at sites $\mathrm{r}$ o and $\mathrm{r} 3$ pointing down-slope with a plunge equal to the slope dip; ablation till seems to have been deposited here, along with talus material. Site 16 shows no preferred orientation as expected from its location on the rock glacier.

\section{RELATIONSHIP OF TILL FABRIC TO GLAGIAL-DEBRIS CHARAGTERISTICS}

An investigation was made to determine if those till fabrics with the strongest preferred orientations might be associated with debris which exhibited the most effects of glacial transportation: that is, rounding, striations and polish. The range of values for each parameter-vector strength, percentage of striated stones, percentage of polished stones, average 


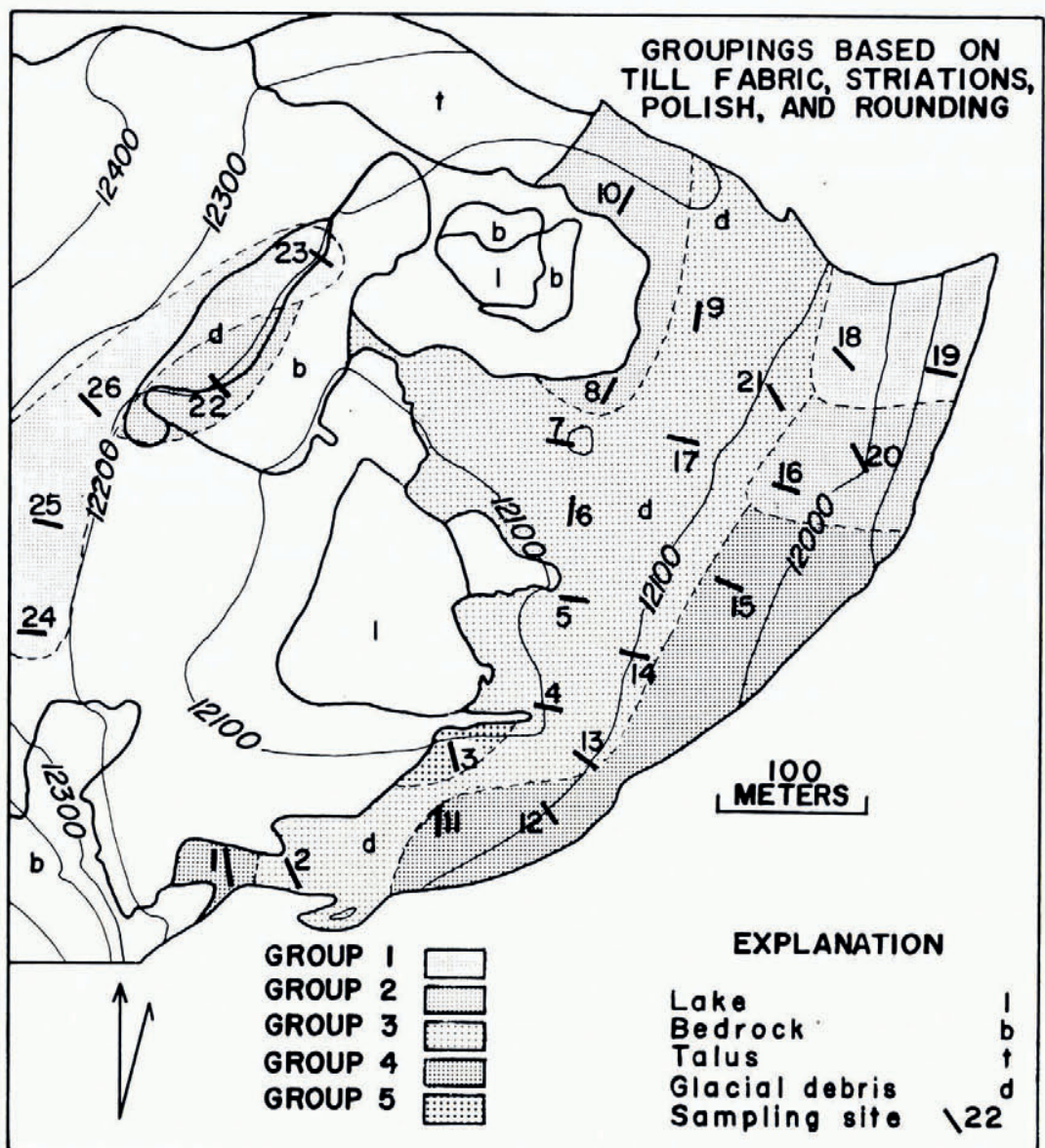

Fig. 6. Map showing groups of sampling sites based on glacial characteristics of stones (including till fabric, polish, striations and rounding) using the GRAPH computer program. Note the similarity to the maps in Figure 5. Ranking of the groups is subjective and is based on the known values of glacial characteristics found at the sampling sites.

roundness and percentage of stones rounded $>0.1$ - was arbitrarily divided into six groups. The 26 moraine sites were each assigned a set of five characters according to these groups. A computer analysis resulted in the division of the moraine sites into five clusters (Estabrook, I966) (Fig. 6). Since the characters are believed to represent effects of glacial transportation, each cluster of sites reflects an amount of such glacial characteristics, the amount increasing with the group number (Fig. 6).

Membership in the clusters was then considered to be a sixth character. A computer program called CHARANAL, developed by Estabrook ( 1967 ), showed that all characters were significantly associated with each other, with one exception. The percentage of stones rounded $>0$. $\mathrm{I}$ is not significantly associated with till-fabric strength, or with percentages of striated and polished stones. The association between percentages of polished stones and average roundness is borderline. In general, the glacial characteristics do associate significantly with the clusters of characters for each sampling site in Figure 6. Strong till fabrics are present at sites with high rounding of stones, polish and striations. 


\section{COMPARISONS OF PAST AND PRESENT PROCESSES}

There is a large difference between the percentages of rounded material produced over the last 50-100 years $(70 \%)$ compared with that produced during the whole of the Gannett Peak stade $(88 \%$ ) (Table I). Accordingly, a tentative estimate of a $10-20 \%$ increase in erosive power of Arapaho Glacier during the Gannett Peak stade is proposed.

Table I. Data on areas, volumes and rates pertaining to the Arapaho Glacier area

\section{Parameter}

Cirque area

Glacier area

Maximum velocity

Moraine volume: minimum

maximum

Gannett Peak debris volume: minimum

Estimated subglacial contribution

Rockfall rate

Denudation rate from suspended sediment load

Denudation rate from ablation moraine

Glacial denudation rates

Denudation rates corrected for ice area, minimum debris thickness, possible Audubon age of part of terminal moraine
Past

$368250 \mathrm{~m}^{2}$

$8.4 \mathrm{~m} /$ year

$728000 \mathrm{~m}^{3}$
$1214000 \mathrm{~m}^{3}$

$76 \mathrm{I} 000 \mathrm{~m}^{3}$

$88 \%$
$290-485 \mathrm{~m}^{3} /$ year

4 920-8 $160 \mathrm{~mm} / \mathrm{I}$ ooo year

I $260-2040 \mathrm{~mm} / \mathrm{I}$ ooo year
Present

$514740 \mathrm{~m}^{2}$ $250900 \mathrm{~m}^{2}$ $5.2 \mathrm{~m} /$ year

$70 \%$ $35-50 \mathrm{~m}^{3} /$ year 2-9 mm/ 1 ooo year 93-1 $55 \mathrm{~mm} / \mathrm{I}$ ooo year 95-165 mm/1 ooo year 1 $40-235 \mathrm{~mm} / \mathrm{s}$ ooo year

This estimated increase in erosive power is seconded by the figures for rate of rockfall. Rockfall rate was observed to have diminished from $290-485 \mathrm{~m}^{3} /$ year during the Gannett Peak stade to $30-50 \mathrm{~m}^{3} /$ year at present (Table I).

It is apparent that well over an order of magnitude difference exists between present $\left(95^{-1} 65 \mathrm{~mm} / \mathrm{I}\right.$ ooo year) and past $(4920-8 \mathrm{I} 60 \mathrm{~mm} / \mathrm{I}$ ooo year) denudation rates by Arapaho Glacier (Table I). Several factors that may account for this difference can be introduced into the calculations in an effort to see if present and past rates could have been comparable. The present denudation rate was calculated using the present ice area; if this rate is adjusted for the area at the Gannett Peak maximum, I obtain a rate of approximately $140-235 \mathrm{~mm} /$ I ooo year for the present. In addition, the estimates of average thickness of morainal debris may be too large. If the terminal moraine is only an average of $10 \mathrm{~m}$ thick, and the ground moraine under the lake only $\mathrm{I} \mathrm{m}$ thick, the denudation rate in the past would be $3560 \mathrm{~mm} /$ I ooo year. Even with these adjustments, there is still more than an order of magnitude difference in the denudation rates.

Two factors remain which could resolve the discrepancy in present and past denudation rates. One is that rockfall rates and glacial erosion were greatly accelerated during the times of maximum extent of Arapaho Glacier. The second factor involves the presence of Audubonaged debris on the south-eastern boundary of the till. If these areas truly represent Audubon till and are not relict rockfall boulders, it is probable that a substantial proportion of the terminal moraine actually consists of Audubon till covered by Gannett Peak till. Since Audubon time lasted approximately 900 years, the terminal moraine could have been produced in 1200 years rather than in only 300 years. This results in a denudation rate of I $260-2040 \mathrm{~mm} / \mathrm{I}$ ooo year and reduces the discrepancy between past and present denudation rates to an order of magnitude. Carrying this analysis one step further, suppose that between the Audubon and Gannett Peak stades, Arapaho Glacier shrank considerably but did not disappear, and in fact maintained its present denudation rate. Allowing the present rate of transport to extend over 2 ooo years results in a theoretical volume of debris of 142 Ooo$242000 \mathrm{~m}^{3}$ as compared to the actual amount of $76 \mathrm{r} 000-\mathrm{r} 268000 \mathrm{~m}^{3}$. The calculated volume is smaller than the actual volume by a factor of 5 . 
Having made all imaginable allowances for variables affecting the estimates of debrisproduction rates, it seems justifiable to state that during the periods of maximum extent of Arapaho Glacier the combined contributions of rockfall and glacial erosion of the bedrock to the glacial load increased by at least a factor of 5 . Similar conclusions were given by Broecker and others (1958) for late Wisconsin deep-sea clay sedimentation rates, and by Church and Ryder ( 1962 ) in a review on denudation rates world-wide.

The amount of time required to erode Arapaho Glacier cirque below the height of its surrounding arête may be calculated from the data in Table I, assuming the cirque floor extends out to the terminal moraine. Using the adjusted Gannett Peak denudation rate, $200000-300$ ooo years are required. Only 40 ooo-70 ooo years, however, are required if the unadjusted Gannett Peak rate is employed. This may have important implications concerning the duration of cirque and valley glaciation in the Colorado Front Range, and suggests the possibility that some of the older Pleistocene glaciations may have been represented by ice-cap glaciers.

Past and present denudation rates in Arapaho Glacier cirque have been calculated as I $260-2040 \mathrm{~mm} / \mathrm{I}$ ooo year and $140-235 \mathrm{~mm} / \mathrm{I}$ ooo year, respectively. The denudation rate for Arapaho Glacier in Audubon and Gannett Peak times is quite comparable to rates quoted for other glaciers (Table II), even though all the data presented are derived from valley glaciers except for that of Andrews (197I) and Andrews and LeMasurier (1973). Even the lower rate of present erosion for Arapaho Glacier is within the range of figures quoted. Perhaps glacial denudation rate is relatively constant without regard to the size of the glacier.

TABLE II. A SUmmary OF SOME DENUdATION RATES FROM BOtH GLACIAL AND NON-GLACIAL AREAS Area

Erosion rate
$\mathrm{mm} / \mathrm{I}$ ooo year
$50-100$

$1.05-1.28$
615
700
640,5500
$280-300$
$25-7300$
$25-90$
$2000-8000$
$100-2000$
$360-460$
7700
$740-235$
$1260-2040$

Method

Reference

World

River loads lowering Ritter (1967) on granite

Norway

River loads lowering Dahl ( 1967 ) on granite

Glacial-periglacial

Alps, Norway, Iceland

Iceland

Baffin Island

British Columbia ro ooo-6 ooo years B.P.

Baffin Island

Rocky Mountains National Park (RMNP)

Baffin Island and RMNP

Marie Byrd Land

Stream load

Suspended load

River load

Moraine volume

Moraine volume

Cirque volume

Cirque volume

St. Sorlin Glacier (France)

Suspended load and

Arapaho Glacier: past present moraine volume

Suspended load and Reheis (unpublished)

Corbel (1959)

Flint (1971, p. 120)

Okko (1955, p. 32)

Church and Ryder (1972)

Church and Ryder (1972)

Andrews (197 I)

Andrews (1971)

Andrews (197 I

Andrews and LeMasurier

(I973)

moraine volume

\section{Acknowledgements}

I should like to express my thanks to the Institute of Arctic and Alpine Research (INSTAAR), University of Colorado, for their field support over the summers of 1972 and 1973. The Warren O. Thompson Fund, administered by the Department of Geological Sciences, University of Colorado, supported work on the electron microscope. Alisa Swartz, Keith Echelmeyer, Doug Duncan and Ted Cassman, high-school participants in INSTAAR's summer research program, assisted in the field work. Mr James B. Johnson, of Mesa College, Colorado, was an invaluable source of suggestions and patience. Drs John T. Andrews and Peter Birkeland, University of Colorado, supervised the research, read the manuscript, and offered much help and constructive criticism.

MS. received II June 1974 


\section{REFERENGES}

Alford, D. L. Unpublished. Cirque glaciers of the Colorado Front Range: mesoscale aspects of a glacier environment. [Ph.D. thesis, University of Colorado, I973.]

Andrews, J. T. 1971. Estimates of variations in glacial erosion from the volume of corries and moraines. Abstracts with Programs, Geological Society of America, Vol. 3, No. 7, p. 493.

Andrews, J. T., and LeMasurier, W. E. 1973. Rates of Quaternary glacial erosion and corrie formation, Marie Byrd Land, Antarctica. Geology, Vol. 1, No. 2, p. 75-80.

Barry, R. G. 1972. Climatic environment of the east slope of the Colorado Front Range. University of Colorado. Institute of Arctic and Alpine Research. Occasional Paper No. 3.

Benedict, J. B. 1967 . Recent glacial history of an alpine area in the Colorado Front Range, U.S.A. I. Establishing a lichen-growth curve. Fournal of Glaciology, Vol. 6, No. 48, p. 81 7-32.

Benedict, J. B. I968. Recent glacial history of an alpine area in the Colorado Front Range, U.S.A. II. Dating the glacial deposits. Fournal of Glaciology, Vol. 7, No. 49, p. 77-87.

Beschel, R. E. 1961. Dating rock surfaces by lichen growth and its application to glaciology and physiography (lichenometry). (In Raasch, G. O., ed. Geology of the Arctic: proceedings of the first international symposium on Arctic geology held in Calgary, Alberta, January $I_{1-13}, 1960$. Toronto, University of Toronto Press, Vol. 2, p. $1044-62$.)

Boulton, G. S. 1967. The development of a complex supraglacial moraine at the margin of Sørbreen, Ny Friesland, Vestspitsbergen. Fournal of Glaciology, Vol. 6, No. 47, p. 71 7-35.

Boulton, G. S. I970. On the deposition of subglacial and melt-out tills at the margins of certain Svalbard glaciers. Fournal of Glaciology, Vol. 9, No. 56, p. 231-45.

Boulton, G. S. 1971. Till genesis and fabric in Svalbard, Spitzbergen. (In Goldthwait, R. P., ed. Till: a symposium. [Columbus], Ohio, Ohio State University Press, p. $4^{1-72 .)}$

Broecker, W. S., and others. 1958. The relation of deep sea sedimentation rates to variations in climate, by W. S. Broecker, K. K. Turekian and S. C. Heezen. American Journal of Science, Vol. 256, No. 7, p. 503-1 7.

Brown, J. E. 1973. Depositional histories of sand grains from surface textures. Nature, Vol. 242, No. 5397, p. $396-98$.

Campbell, R. C. 1967. Statistics for biologists. Cambridge, University Press.

Church, M., and Ryder, J. M. 1972. Paraglacial sedimentation: a consideration of fluvial processes conditioned by glaciation. Geological Society of America. Bulletin, Vol. $8_{3}$, No. 10, p. 3059-71.

Corbel, J. 1959. Vitesse de l'érosion. Zeitschrift für Geomorphologie, Bd. 3, Ht. 1, p. I-28.

Corbel, J. 1962. Neiges et glaciers. Paris, Armand Colin.

Dahl, R. 1967. Post-glacial micro-weathering of bedrock surfaces in the Narvik district of Norway. Geografiska Annaler, Vol. 49A, Nos. 2-4, p. 155-66.

Drake, L. D. 1971. Evidence for ablation and basal till in east central New Hampshire. (In Goldthwait, R. P., ed. Till: a symposium. [Columbus], Ohio, Ohio State University Press, p. 73-91.)

Estabrook, G. F. 1966. A mathematical model in graph theory for biological classification. Fournal of Theoretical Biology, Vol. 12, No. 3, p. 297-310.

Estabrook, G. F. I967. An information theory model for character analysis. Taxon, Vol. 16, No. 2, p. 86-97.

Flint, R. F. 197i. Glacial and Quaternary geology. New York, John Wiley and Sons, Inc.

Goldthwait, R. P. 1971. Introduction to till, today. (In Goldthwait, R. P., ed. Till: a symposium. [Columbus], Ohio, Ohio State University Press, p. 3-26.)

Harris, S. A. 1968. Till fabrics and speed of movement of the Arapahoe Glacier, Colorado. Professional Geographer, Vol. 20, No. 3, p. 195-98.

Holmes, C. D. I96o. Evolution of till-stone shapes, central New York. Bulletin of the Geological Society of America, Vol. 71, No. 11, p. 1645-6o.

Krinsley, D. H., and Donahue, J. rg68. Environmental interpretation of sand grain surface textures by electron microscopy. Geological Society of America. Bulletin,Vol. 79, No. 6, p. 743-48.

Margolis, S. V., and Kennett, J. P. I 97 I. Cenozoic paleoglacial history of Antarctica recorded in subantarctic deep-sea cores. American Journal of Science, Vol. 271, No. 1, p. 1-36.

Okko, V. 1955. Glacial drift in Iceland, its origin and morphology. Bulletin de la Commission Géologique de Finlande,

No. I 7o.
Reheis, M. J. Unpublished. Source, transportation, and deposition of debris on Arapaho Glacier, Front Range, Colorado. [M.S. thesis, University of Colorado, 1974.]

Ritter, D. F. 1967 . Rates of denudation. Fournal of Geological Education, Vol. 15, No. 4, p. 154-59:

Sharp, R. P. 1949. Studies of the supraglacial debris on valley glaciers. American fournal of Science, Vol. 247, No. 5, p. 289-315.

Waldrop, H. A. r964. Arapaho Glacier, a sixty-year record. University of Colorado Studies. Series in Geology, No. 3 ,

Webber, P. J., and Andrews, J. T. 1973. Lichenometry: a commentary. Arctic and Alpine Research, Vol. 5, No. 4, p. 295-302. 